地すべり 第 25 巻 第 1 号

Journal of Japan Landslide Society 25-1 (1988)

$$
\text { すべり面拡大モデルによるクリープ現象の解析 }
$$

\title{
Analysis of Creep Phenomenen by the Slip Surface Enlarging Model
}

$$
\begin{aligned}
& \text { 大村 寛* 土 屋 智* } \\
& \text { Hiroshi OHHMURA }
\end{aligned}
$$

\begin{abstract}
The creep curve of landslide is composed of three parts in the process of strain to rupture. The curve of primary creep is approximated in the growth function. The secondary steady creep is given in a linear function. The tertiary creep to rupture is shown in an exponential curve. In order to forecast the rupture time till the final.abrupt failure, the mathematical model on these creep curves was analyzed on the basis of the idea that the stress concentration would drive a progressive failure in landslide. It was presumed that the strain velocity of landslide depending on the stress would concentrate on the unbroken effective sphere which resisted the shear force in the potential sliding surface. Then the relationship between the concentrated stress and the strain velocity was given as follows, $d e / d t=-A / S^{a}$, where $e$, $t, A$, and $S$ are strain, time, coefficient, and effective unbroken sphere in the sliding surface respectively. By integrating the equation for the exponential power $a=-1,0,1, \cdots \cdots, n$ at the initial condition $S=S_{0}$ to $t=0$ and at the terminal condition $S=0$ to rupture time $t=t_{r}$. the solutions corresponding to the each creep curve could be deducted and given the fundamental base to forecast tee final rupture time.
\end{abstract}

\section{1. まえがき}

地すべりあるいは斜面崩壊の発生時刻を予測するには その誘因による方法と地盤の変化に着目した方法とがあ げられる1”。斜面上部に発生した亀裂が拡大して崩壊に 至るか：それとも途中で止るのか，も乙崩壊するもの とすればいつなのかといった比較的近い未来の予測には 後者による方法が最も信頼性は高くかつ実用的である。 すなわち，これは土の“時間とヒズミ変化(Fig. 1)”に 着目したクリープ破壊論に基づく研究成果であり，斉

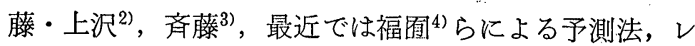
オロジーモデルから Fig. 1 に示す土の挙動を数式化し 地すべりの移動を経時的に説明した駒村5) の研究等であ る。

これらの研究のなかで斎藤は定常 2 次クリープ段階で 定常ヒズミ速度 $\dot{\varepsilon}$ とクリープ破壊時間 $t_{r}$.とが逆比例の 関係にあることを示した判定図法による予測法とクリー プが進行し第 3 次クリープの段階でも同じ関係が成立す るとして近接予測，また精密予測法を明らかにしている。 一方, 福图は第 3 次クリープ段階での表面移動速度と表 面加速度との関係が対数軸上においてほぽ直線関係下に

$*$ 静岡大学農学部

Faculty of Agriculture, Shizuoka University
あることを確かめ，これを時間に関し 1 回積分し速度の 逆数をもって崩壊時間の予測を行なっている。

本論文は土のセン断時での進行性破壊の概念(6),7) を考 慮した破壊モデルを仮定し，この仮定に基づく微分方程 式の解が斉藤式あるいは福苜式を満足すること，また両 式で用いられているパラメータに対する定量的裏付けが 可能であることを示すとともに実験データを適用した結 果について若干の考察を加えるものである。

\section{2. 進行性破壊とモデルの仮定}

Bjerrum ${ }^{8)}$ は土のピーク強度, 残留強度の関係からす ベり面発達の過程を遂次破壊によるものと考兄，肩所的 にセン断強度がピーク強度を越えることが進行性破壊を 発生させる第一条件であると説明している。現実での斜

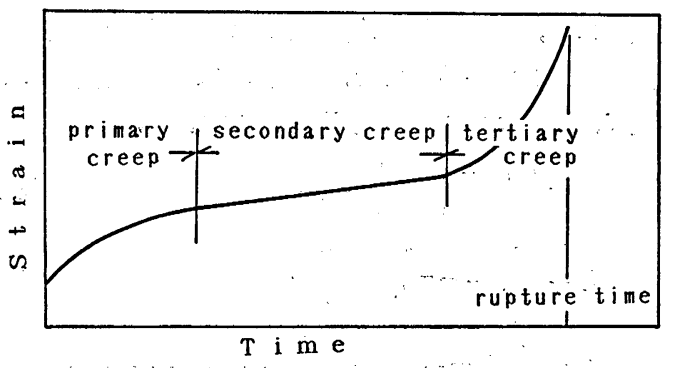

Fig. 1 The schematic creep curve 
面を想定すれば，一部の空隙や地層あるいは岩種・岩質 の違いといった物理的, 強度的不連続面に沿う弱層の存 在が，斜面全体は安定であっても弱層部分では，斜面方 向の滑動力によりヒズミが進行しピーク強度を越える場 合があり，これを引き金としてすべり面が形成され破壊 する可能性が高いことを示したものと理解されよう。

上述の進行性破壊に対する概念は，土の強度特性であ る応力ーヒズミ関係からそのメカニズムについて言及し たものであるが，地すべりあるいは崩壊の予知・予測に 関しては Fig. 1 に示す土のヒズミ一時間関係を進行性 破壊の概念と結びつけることが重要である。すなわち， 局部的にすべり面が形成された部分では強度が低下し, Ter-Stepanian" ${ }^{9)}$ が指摘するようにその状態で新たにす ベり面が形成されていない部分でのセン断応力の再配分 が行なわれるものとすれば, 未だセン断されていない部 分でのセン断応力はすべり面の拡大に伴って時々刻々と 増大する一途をたどることになる。すべり面が抎大して いない段階では初期の一時的なヒズミ増大を緩和するよ らにヒズミの時間増加率は時間とともに小さくなり，こ の場合は Fig. 1 亿示す第一次クリープ状態を示すが, 第二次クリープから第三次クリープヘの移行は概ね上述 のよらなメカニズムで進行することが予察される。この 過程では潜在すべり面に沿って動員される有効なセン断 抵抗力はすべり面の拡大とともに指数関数的減少し, ヒズミ速度は加速的に増大することが予想される。

この考光から, 有効なセン断抵抗力を発揮すると期待 できる潜在すべり面の面樻を $S$, その面積ヒズミ速度を $d \varepsilon / d t$ とし，次式を仮定する。

$$
\frac{d \varepsilon}{d t}=A \cdot S^{-a}
$$

(1) 式に括いて，aはべき乗数，Aは $a$ の変化に従う 有次元数を表わす。ここで, セン断されたすべり面に着 目して (1) 式をすべり面拡大モデルと呼ぶことにする。 初期状態と最終とを規定すれば，

(初期状態)

$$
t=0 ; S(0)=S_{0}, \varepsilon=0
$$

\section{（最終状態）}

$$
t=t_{r} ; S\left(t_{r}\right)=0, \quad \varepsilon=1
$$

ここに, $S_{0}$ は $t=0$ に扮ける潜在すべり面の面積, $\varepsilon$ は 面積ヒズミ， $t_{r}$ は土塊が 完全にセン断された状態での 時刻を表わしている。また，面樻ヒズミ $\varepsilon$ ，面積ヒズミ

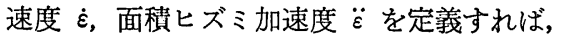

$$
\begin{aligned}
& \varepsilon(t)=\left(\frac{S_{0}-S(t)}{S_{0}}\right) \ldots \ldots \\
& \dot{\varepsilon}(t)=\frac{d \varepsilon}{d t}=-\frac{1}{S_{0}} \cdot \frac{d S}{d t} \\
& \dddot{\varepsilon}(t)=\frac{d^{2} \varepsilon}{b t^{2}}=-\frac{1}{S_{0}} \cdot \frac{d^{2} S}{d t^{2}}
\end{aligned}
$$

で表わされる。（1）式の $A$ が滑動中変化しないものと すれば新たに定数 $K$ を用い(1) 式と（5）式から $K=$ $A \cdot S_{0}$ とすることにより，

$$
\frac{d S}{d t}=-K \cdot S^{-a}, K=A \cdot S_{0}
$$

緟密な意味で崩壊時での $A$ は時間とともに移動土塊の 滑動に応じて変化することが予想されるが，ここでは (7) 式の取扱いの簡便さを考虑して時間に関し定数であ ると仮定する。

\section{3. クリープ曲線に対する検討}

（7）式の微分方程式の解は $a=-1, a=n$ の場合に より得られる一般解が異なる10)。ここでは，それぞれの 場合について（7）式から得られる解について考察する。

(1) $a=-1$ の時

（7）式は次のように表示される。

$$
\frac{d S}{d t}=-K \cdot S
$$

（8）式の一般解は

$$
\ln S=-K \cdot t+C
$$

初期条件から， $t=0$ の時 $S(0)=S_{0}$, すなわち $C=\ln S_{0}$ よって（9）式は

$$
S=S_{0} \exp (-K \cdot t)
$$

（10）式を（4）式に代入すれば面積ヒズミ

$$
\varepsilon=1-\exp (-K \cdot t)
$$

と定められる。（11）式は, 粘弾性理論によるVoight モデル11を表現して拉り，また，Fig. 1 とよればこの関 係は第一次クリープ段階でのヒズミ一時間の関係にも相 当する。（11）式をFig. 2 亿図示するが，時間が無限大 に近づけば $\varepsilon=1$ となり，(4) 式からも理解されるよう に $S(t)=0$ の状態（すべりに抵抗する有効なすべり面 積が存在しない）を示す。

(2) $a=n$ の時

（7）式の表示は

$$
\frac{d s}{d t}=-K \cdot S^{-n}
$$

（12）式を積分し，初期条件を考虑すれば

$$
S=\left(S_{0}^{n+1}-K \cdot(n+1) \cdot t\right)^{1 /(n+1)}
$$

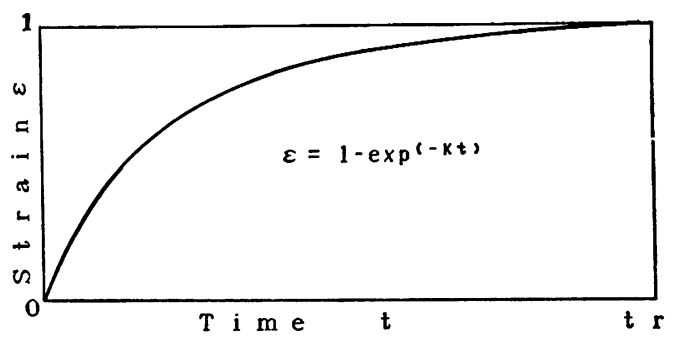

Fig. 2 Model of primary curve 


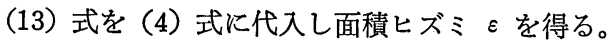

$$
\varepsilon=-\left[1-\left(\frac{1}{S_{0}}\right)^{n+1} \cdot(n+1) \cdot K \cdot t\right]^{n+1} . .
$$

（14）式に特いて，最終条件 $t=t_{r}$ 時を考えれば（3） 式を用い

$$
\begin{aligned}
& 1-\left(\frac{1}{S_{0}}\right)^{n+1} \cdot(n+1) \cdot K \cdot t_{r}=0, \\
& \left(\frac{1}{S_{0}}\right)^{n+1}=\left\{(n+1) \cdot K \cdot t_{r}\right\}^{-1} \\
\therefore \quad & \varepsilon=1\left(1-\frac{t}{t_{r}}\right)^{1 /(n+1)}, \quad t_{r}=\frac{S_{0}^{n+1}}{(n+1) \cdot K}
\end{aligned}
$$

となる。

（15）式，(13)式において，a=0，a=1 の場合はそれ ぞれ $n=0, n=1$ を代入することにより

(1) $a=0$ の時

$$
S=S_{0}-K \cdot t, \quad \varepsilon=\frac{1}{t_{r}} \cdot t, t_{r}=\frac{S_{0}}{K}
$$

(2) $a=1$ の時

$$
\begin{aligned}
& S=\left(S_{0}{ }^{2}-2 \cdot K \cdot t\right)^{1 / 2}, \quad \varepsilon=1-\left(1-\frac{t}{t_{r}}\right)^{1 / 2}, \\
& t_{r}=\frac{S_{0}{ }^{2}}{2 \cdot K} \quad \ldots \ldots \ldots \ldots \ldots \ldots \ldots \ldots \ldots \ldots \ldots \ldots \ldots \ldots \ldots \ldots \ldots \ldots \ldots \ldots \ldots \ldots \ldots \ldots
\end{aligned}
$$

を得る。Fig. 3は（16式）を表現したものであるが, 時 間に対して面積ヒズミが比例関係にあることを示し，こ れは第二次定常クリープ段階を表わしている。また， (17）式における $\varepsilon$ と無次元表示された $t / t_{r}$ 関係式は $n=1$ の時に 2 次式で表わされるが， $n>1$ の場合には Fig. 4 から判断されるように $\varepsilon$ が相対時間 $t / t_{r}$ に対 し指数関数的な増大を示し，この関係は第三次クリープ 段階に相当する。なお $n>1$ の場合（15）式のヒズミ一

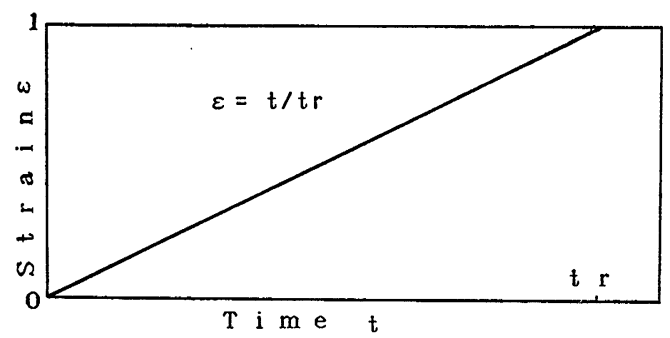

Fig. 3 Model of seconpory creep curve

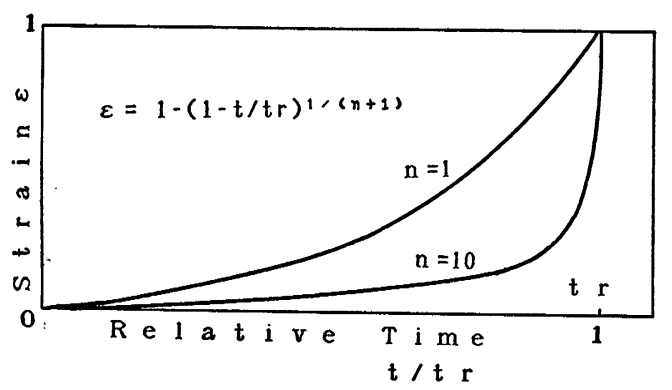

Fig. 4 Model of tartiary curve
相対時間 $t / t_{r}$ は Taylor 展開により,

$$
\varepsilon=A \cdot t^{n}
$$

の形式を示すことが容易に認められる。(18)式は駒村11) が，第三次クリープのヒズミ予測式に用いたものと同一 形であり,この意味からも（15）式が第三次クリープ段 階を表現するものであることは理解されよう。

以上の結果から，(7) 式で与えられる微分方程式から 得られる解は $a$ のべき乗数の值によって, $a=-1$ の時 には第一次クリープ段階， $a=0$ の時には第二次クリー プ段階, また $a \geqq 1$ では第三次クリープ段階を表現する ことが明らかとなった。このようにaの值によって各段 階での土のクリープ特性が表現されるということはまた 各段階を支配する現象がそれぞれに異なった物理的現象 であると理解される。すなわち，レオロジー理論13)が教 えるように土の弾性, 粘性, 塑性といった挙動が土のク リープ特性の各段階と密接に関係し，それぞれの段階に 执いて影響度合が異なっていることを対比すれば，上述 の理解が容認されよう。

\section{4.ヒズミ速度，ヒズミ加速度に対する検討}

前項での（11）式，(15）式と（5）式，(6) 式の面積 ヒズミ速度, 面積ヒズミ加速度の式から出発する。

(1) $a=-1$ の時

（11）式を（5）式の定義から時間 $t$ で微分すれば

$$
\frac{d \varepsilon}{d t}=K \cdot \exp (-K \cdot t)=K(1-\varepsilon)
$$

また（19）式を（6）式に従い時間で微分し面積ヒズ ミ加速度 $\ddot{\varepsilon}$ を求めれば,

$$
\frac{d^{2} \varepsilon}{d t^{2}}=-K^{2} \cdot \exp (-K \cdot t)=-K^{2}(1-\varepsilon) \text {. }
$$

（19）式，(20）式から明らかなように，ヒズミとが小 巳い時に $\dot{\varepsilon}, \ddot{\varepsilon}$ は大きく, $\varepsilon$ の増大 (最大值 $\varepsilon=1$ ) に 従って, $\dot{\varepsilon}, \ddot{\varepsilon}$ は減少することがわかる。

(2) $a=n$ の時

前回同様に（15）式を時間で微分すれば，

$$
\begin{aligned}
\frac{d \varepsilon}{d t} & =\frac{1}{n+1} \cdot \frac{1}{t_{r}} \cdot\left(1-\frac{t}{t_{r}}\right)^{-n /(n+1)} \\
& =\frac{1}{n+1} \cdot \frac{1}{t_{r}} \cdot(1-\varepsilon)^{-n} \quad \ldots \ldots \ldots \ldots . . .
\end{aligned}
$$

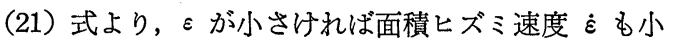

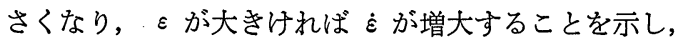
この関係は（19）式の性質とは逆である。ここで，(21） 式の両辺の常用対数をとれば,

$$
\begin{aligned}
\log \left(\frac{d \varepsilon}{d t}\right)= & \log \left(\frac{1}{n+1} \cdot \frac{1}{t_{r}}\right) \\
& -\frac{n}{n+1}\left[\log \left(t_{r}-t\right)-\log t_{r}\right] \\
\therefore \quad \log \left(t_{r}-t\right) & =\log \left\{t_{r}-1 / n \cdot(n+1)^{-(1+1 / n)}\right\}
\end{aligned}
$$




$$
-\left(1+\frac{1}{n}\right) \cdot \log \left(\frac{d \varepsilon}{d t}\right)
$$

(27) 式に拈いて $1 / n \doteqdot 0$ と近似すれば,

$$
\log \left(t_{r}-t\right)=\log (n+1)-\log \left(\frac{d \varepsilon}{d t}\right)
$$

となり，斉藤が図式判定法に用いた $\log \left(t_{r}\right)=2.33$ $-0.916 \log \dot{\varepsilon} \pm 0.59$ において $\log$ の係数 $0.916 \doteqdot 1$ の 取扱いを理論的に襄づける結果を示す。

また，(21）式をさらに時間で微分し，面積ヒズミ加 速度 $\ddot{\varepsilon}=d^{2} \varepsilon / d t^{2}$ を求めれば

$$
\begin{aligned}
\frac{d^{2} \varepsilon}{d t^{2}}= & \frac{n}{(n+1)^{2}} \cdot \frac{1}{t_{r}^{2}} \cdot\left(1-\frac{t}{t_{r}}\right)^{-(2 n+1) /(n+1)} \\
= & \frac{n}{1-\varepsilon} \cdot\left(\frac{d \varepsilon}{d t}\right)^{2} \\
& \left(\because \frac{1}{1-\varepsilon}=\left(1-\frac{t}{t_{r}}\right)^{-1 /(n+1)}\right)
\end{aligned}
$$

または

$$
\begin{aligned}
\frac{d^{2} \varepsilon}{d t^{2}}=n \cdot\left\{(+1) \cdot t_{r}\right\}^{1 / n} \cdot\left(\frac{d \varepsilon}{d t}\right)^{2+1 / n} \\
\left(\begin{array}{l}
\because \frac{1}{1-\varepsilon}=\left(\frac{d \varepsilon}{d t}\right)^{1 / n}(n+1)^{1 / n} \cdot t_{r^{1 / n}} \\
(21) \text { 式より }
\end{array}\right)
\end{aligned}
$$

（25）式に拈いて $1 / n \fallingdotseq 0$ と近似すれば,

$$
\frac{d^{2} \varepsilon}{d t^{2}}=n \cdot\left(\frac{d \varepsilon}{d t}\right)^{2}
$$

と表現される。福目は実験的に崩塤直前の表面移動速度 と加速度との関係が対数関係下に扣いてほぼ直線となる 範囲が存在することから，この関係を次式で示した。

$$
\frac{d^{2} x}{d t^{2}}=a\left(\frac{d x}{d x}\right)^{\alpha}
$$

ただし， $x$ : 表面移動量, $t$ : 時間, $d^{2} x / d t^{2}$ : 表面移 動加速度, $d x / d t$ : 表面移動速度, $a, \alpha$ : 定数であり, また $\alpha$ の範囲として $1.5<\alpha<2.2$ が実験結果から求 められることを報告している。移動量 $(x)$ を面積ヒズ ミ量 $(\varepsilon)$ に置き換えると (26) 式と (27) 式とは式形が 全く一致する。これより，(26）式は（27）式の $\alpha$ が理 論的に $\alpha=2$ であることを裹づけたものであると判断す ることができる。

$a=0, a=1$ の場合には(21)式, (25) 式に $n=0, n=1$ を代入することによりそれぞれ次の関係が得られる。

(1) $\alpha=0$ の時

$$
\frac{d \varepsilon}{d t}=\frac{1}{t_{r}}, \frac{d^{2} \varepsilon}{d t^{2}}=0
$$

(2) $a=1$ の時

$$
\begin{aligned}
& \frac{d \varepsilon}{d t}=\frac{1}{2 \cdot t_{r}} \cdot\left(1-\frac{t}{t_{r}}\right)^{-1 / \lambda_{2}}=\frac{1}{2 \cdot t_{r}}(1-\varepsilon)^{-1} \\
& \frac{d^{2} \varepsilon}{d t^{2}}=\frac{1}{1-\varepsilon}\left(\frac{d \varepsilon}{d \cdot t}\right)^{2}=2 \cdot t_{r} \cdot\left(\frac{d \varepsilon}{d t}\right)^{3} \ldots \ldots \ldots . . .
\end{aligned}
$$

$a=0$ の時は前述のように第二次定常グリープ段階を 示したものである。（28）式において，面䅪ヒズミ速度 とクリープ破壊時間の逆数 $1 / t_{r}$ の常用対数をとれば,

$$
\log \left(\frac{1}{t_{r}}\right)=\log \left(\frac{d \varepsilon}{d t}\right)
$$

となる。この関係を斉藤の判定図に当てはめれば，定常 ヒズミ速度が $10^{-3}$ /分の時, クリープ破壊時間は $10^{3}$ 分, また $\varepsilon=10^{-4} /$ 分 では $10^{4}$ 分となる結果を示す。また，

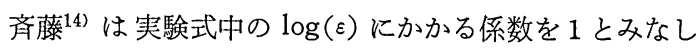

$$
\varepsilon=214 / t_{r}
$$

なる関係を導びいているが，これは (31) 式と同一形式 関の係式である。今回，具体的な検討は行なっていない が，仮定した（1）式の右辺に定数項を付加することに より（31）式の左辺には付加した定数項が乗じられる可 能性があり, その場合には（32）式と（31）式とは同一 の関係を示す。

以上での考察を $a=-1, a=0, a \geqq 1$ の各場合でま とめると次の通りである。

第一次クリープを表現する $a=-1$ の場合には面積七 ズミ速度, 面積加速度を評価する際に定数として取扱っ た $A$ の定量化が必要となる。地すべり・崩壊の予知・ 予測ではヒズミが進行した直前予测の重要性については 改めて述べるまでもないが, 初生すべりを取扱う場合は 第一次クリープ段階でのクリープ特性の評価が必要不可 欠であり，今後は（19）式（20）式を用いた $K$ の具体 的な定量化が求められる。また， $a=0$ の場合の定常ク リープ段階では（28）式にも示すように面積ヒズミ加速 度は発生しない。この段階では面積ヒズミ速度とクリー プ破壊時間とは逆比例の関係下にあり, 破壊時刻の予测 を簡単に行ならことが可能である。しかしながら, 定常 クリープ段階では破壊せず，破壊を発生させるためには 第二次のクリープから第三次のクリープヘと移行しなけ ればならない。この移行条件を明らかにすることは今後 の重要な 課題であるが，（31）式あるいは（32）式はこ の段階での破壊時間の予測が可能であることを示してい る。

最後に $a \geqq 1$ の場合であるが，この場合は第三次クリ ープ段階に相当し, 面積ヒズミ速度, 面積ヒズミ加速度 からそれぞれ斉藤式, 福固式が得られることになり, 各式 でのパラメータの一部を理論的に定量化でさることを示 した。特に, 斉藤式は $\log (\dot{\varepsilon})$ の係数が 1 である時 $a=0$ の定常二次クリープ式と $a \geqq 1$ の第三次クリープ式から 得られる面積ヒズミ速度 $\varepsilon$ と破壊時間 $t_{r}$ とは同一形式 を示す点で興味深い。

\section{5. 安全率の時間的低下に関する考察}

粘性土より成る斜面 $(c \neq 0, \phi=0)$ を考えると, すべ り面に沿っての粘着力のみが抵抗成分となり, 抵抗力は 


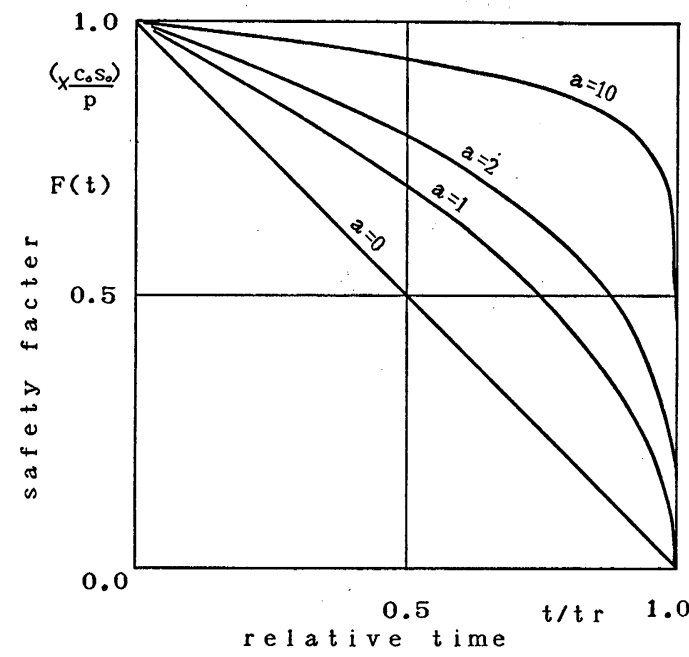

Fig. 5 Changes of safaty factor with relative time

粘着力メすべり面積で与えられる。安全率 $F$ は抵抗力 に対する滑動力の比で求められることから, 滑動中に粘 着力と滑動力が変化しないものとすれば, 安全率 $F$ は面 積 $S$ に比例することになる。すなわち，滑動力を $p$ と すれば,

$$
F(t)=\frac{c}{p} \cdot S(t)
$$

$\dot{a}=n$ の場合とし，(4) 式，(15式）を用いれば

$$
F(t)=\frac{c}{p} \cdot S_{0} \cdot\left(1-\frac{t}{t_{r}}\right)^{1 /(n+1)}
$$

$a=0$ の場合での定常クリープ段階では（34）式から,

$$
F(t)=\frac{c}{p} \cdot S_{0}\left(1-\frac{t}{t_{r}}\right)
$$

（34）式（35）式を図示すれば Fig. 5 に示す通りで ある。Fig. 5 から $a=0$ の時は破壊時間比 $t / t_{r}$ の増 大とともに線型に安全率 $F$ が減少し, $t / t_{r}$ の増大が安 全率 $F$ の低下に与える影響は最も大きいが， $a=1$, $a=2 \cdots \cdots$ と $a$ が増加するにつれて $t / t_{r}$ の増大が $F$ の低下に影響しにくく，時間 $t$ が破壊時間 $t_{r}$ に近づく と急激に安全率が低下する様子がうかがえる。ここでの 事例は粘性土のみを有する場合の安全率の時間的低下に 関する結果を示したものであるが, Fig. 3, Fig. 4 に示 す $\varepsilon$ と $t / t_{r}$ の関係が得られれば $a$ の值を推定するこ とが可能となり，ここで述べたような方法により安全率 の時間的な変化を推察することができよう。

\section{6. 事例からの検討}

Fig. 6 の曲線は（15）式を図示したもので，Fig. 4 に拈ける $\varepsilon=0.4$ 以下を拡大したものである。図中には (1)東北本線浅虫一野内間 $724^{\mathrm{k}} 846^{\mathrm{m}}$ 付近地すべり移動 観測記録 ${ }^{15)}$ の結果，(2)地すべりから採取した土の一軸載 荷方式によるクリープ試験16)の結果执よび(3)砂を用いた

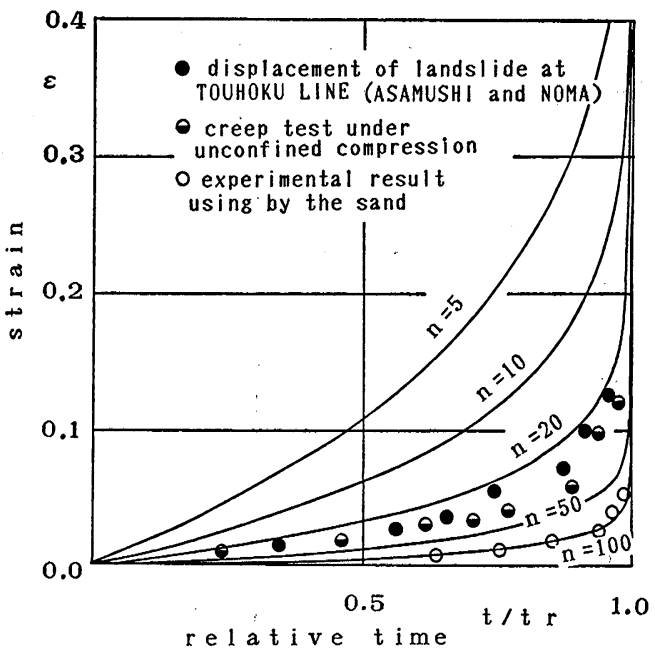

Fig. 6 Relationship between $\varepsilon$ and $t / t_{r}$

室内降雨崩壊実験による移動量記 ${ }^{17}$ 録等をもとに第二次 クリープ，第三次クリープ段階でのヒズミと相対時間 $t / t_{r}$ を求め, これらの関係がプロットされている。た だし，ここでは滑動中土塊幅が一定であるものとし，ヒ ズミもが面積ヒズミに置き換えられるものとした。Fig， 6 によれば，いずれもヒズミ $\varepsilon$ は相対時間 $t / t_{r}$ に対し 指数関数的に増大し, 特に $t / t_{r}$ が 0.8 以上ではその増 大が著しい。また，砂を用いた崩壊実験による結果では べき乗数 $n \fallingdotseq 100$ 程度で近似されるのに対し, 現地の地 すべり記録，または粘着性を有すると思われる地す心゙り 地の試料による結果では $n$ はほぼ 30 以上 50 以下程度の 範囲で近似されるようである。このことは主に砂質土に より構成される斜面の場合ではヒズミとが相対的に小さ い段階で急激に崩壊するのに対し粘着性を有する地すへ り性崩壊などでは，比較的移動現象が明らかになった後 崩壊するといった両者の崩壊現象の違いに対比されるも のと考えることができる。

Fig. 7 は (24) 式をもとにヒズミ速度 $d \varepsilon / d t$ と相対 時間の関係 $t / t_{r}$ を示したものである。図から時間 $t$ が 崩壊時刻 $t_{r}$ に近づくに従ってヒズミ速度が指数関数的 に増大する様子が理解できる。図中黒点は飯山線高場山 トンネルの地すべり崩壊での地すべり計 $S-27$ の記録と これから得られた判定図 ${ }^{18)}$ をもとにビズミ速度 $d \varepsilon / d t$ と相対時間 $t / t_{r}$ の関係を記入したものである。この際 （23）式中にはべき乗数 $n$ が含まれるため，これを予め 定めなければならないが，Fig. 6 での結果を参考にこ の事例では $n=30$ と仮定している。図に示した結果か ら, $t / t_{r}$ が 0.7 以下では曲線よりもやや下方に黒印が 位置することになるが， $t / t_{r}>0.7$ の段階ではほぼ曲線 に沿って増大することがわかる。

以上での結果が示すように今回のモデルは定常二次ク リープ，第三次クリープの段階であれば, 崩壊発生前で 


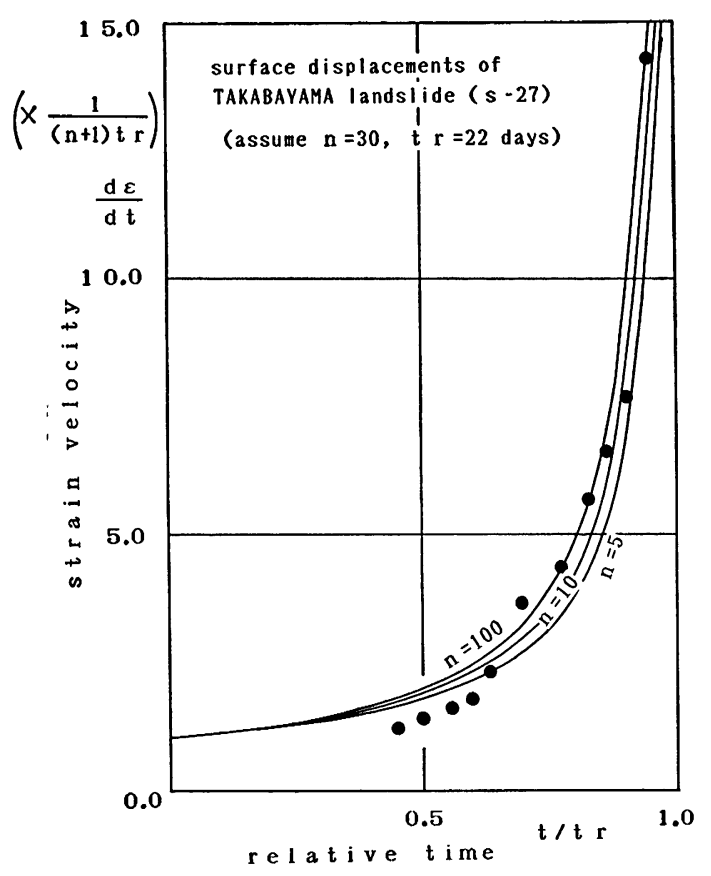

Fig. 7 Relationship between $d \varepsilon / d t$ and $t / t_{r}$

の移動量を時間との関係をたは移動速度と時間との関係 のいずれも満足することが確められる。とはいっても具 体的な事例は少なく，nの定量的評価の問題とともに現 地観測資料結果, 室内崩壊実験結果等からこれらの関係 確認を補らことが大切である。

\section{7. 結 語}

斜面崩壊の予知・予測に関しては斉藤のクリープ理論 にもとづく予測が数多くの地すべりに適用され信頼性も 高い。また最近提案された崩壊予測法に移動速度の逆数 を用いる福直の方法があり, 1985年に発生した長野県地 附山地すべりに適用し実際の崩壊時間とほぼ一致した結 果を得ている。両法ともに地すべりあるいは崩壊での時 間一移動量関係から出発する予測方法であり，筆者らは 両手法の相違点, 共通点について興味を覚方簡単な微分 方程式を仮定することによりこの問題にアプローチした。 得られた知見を要約すれば以下の通りである。

（1）仮定したすべり面減少モデルを積分し，べき乗数 を $a=-1$ とすれば, これは第一次クリープ段階を 表わす。

(2) (3)を同様に， $\quad a=0$ とすれば，第二次定常クリー プ段階を，一般に $a \geqq 1$ と打けば，第三次クリープ 段階を表わす。

(3) $a \geqq 1$ のヒズミ速度式（21）において $1 / n \doteqdot 0$ と近 似すれば,斎藤式と同一形式のものが得られまた理 論的に斉藤式の $\log$ に乗ぜられる係数が 1.0 となる。

（4）（3）での係数を 1 とすれば，定常二次クリープ速度
と崩壊時間 $t_{r}$ とが逆数の関係下にある。

(5) ヒズミ速度式（21）を微分しヒズミ加速度式を得

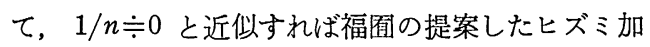
速度式に执いてべき乗数 $\alpha$ は 2 となる。

（6）粘性土斜面では，安全率とすべり面稓の時間的変 化の関係を用いることにより, 安全率の時間的変化 を追求できる可能性がある。

(7) 既往の地すべり, 室内崩壊実験等のヒズミ一時間 の関係は今回得られたヒズミ一相対時間関係, ヒズ ミ速度一相対時間関係をほほぼ満足する。

ここで用いた諸式には，それぞれに打いて理想状態に 近い仮定を含んだものである。今後, 室内実験, 現地資 料等に基ついた確認と諸式において用いられている定数 項の定量的解明に努めたいと考兄ている。

\section{参考文献}

1）山口真一：地すべりの予発予測について, Proceedings of The First International Symposium on Landslide Control（地すべりと対策に関する研究討論会概要）, 1972, 10 月, pp. $167 \sim 170$.

2）蚉藤迪孝・上沢 弘 : 斜面崩壊期期の予知, 地すべり Vol. 4, No. 2, 1966, pp. 7〜12.

3）斎藤迪孝 : 第 3 次クリープによる斜面崩壊時期の予知, 地 すべり, Vol. 4, No. 3, 1968, pp. 1 8.

4）福备輝旗: 表面移動速度の逆数を用いた降雨による斜面崩 壊発生時刻の予測法, 地すべり, Vol. 22, No. 2, 1985, pp. 8 13.

5）駒村富士弥：地すべり土の挙動に関するレオロジー的研究 (II), 新砂防 Vol. 29, No. 2, 1976, pp. 17 19.

6) N. N マスロフ・大草重康他訳：地すべり工学, 森北出版, 1980, pp. $118 \sim 121$.

7）山口柏樹: 土質力学, 技報堂, 1979, pp. 334 335.

8) L. Bjerrum : Progressive foilure in slopes of overconsolidated plastic clay and clay shales, A.S.C.E., SM 5, September, 1967, pp. 3 11.

9) Ter-Stepanian : Correlation between the Rheological Properties of Soils and the Behaviour of Landslides, Proceedings of the Second International Symposium on Landslides and their Control (大八木規夫訳, 第 2 回地すべりと対策に関する国際研究討論会概要)，1977，7 月, pp. $45 \sim 58$.

10）西村勇城：微分積分学, 榎畫店 1973, pp. 69.

11）駒村富士弥：地すべり土の挙動に関するレオロジー的研 究(II), 新砂防, Vol. 29, No. 2, 1976, pp. 17 19.

12）岡小天編著：レオロジー入門，工業調査会， 1970, pp. $138 \sim 143$.

13）駒村富士弥地：すべり土の挙動に関するレオロジー的研究 (I), 新砂防 Vol. 22, No. 1, 1973, pp. 7 12.

14）斎藤迪孝：斜面崩塤発生時期の予知に関する研究，鉄道技 術研究報告, 1968, 2 月, pp. 27 28.

15）同上, pp. 43.

16）駒村富士弥：地すべり性崩壊発生時期の予測に 関する研 究, 文部省科学研究費研究報告䡒, 1983,3 月, pp. 36 .

17）大村 寛：土首の不均質，特に構造欠陥の表居崩壊に及ほ す影響, 文部省科学研究费, 豪雨による表屑崩塤の発生に 関する研究, 1983，3月, pp. 51 .

18）山田剛二・小橋澄二・草野国重 : 高場山トンネルの地すべ りによる崩塤, 地すべり, Vol. 8, No. 1, 197, pp. 20. 
地すべり面拡大モデルによるクリープ現象の解析

「地すべり」Vol. 25, No. 1 (通巻第93号) 1988年（昭和63年）6月

大村寛, 土屋 智

セン断時に括ける面積ヒズミ速度とすべり面の面積 $S$ の指数関数的減少とが比例関係を示すと仮定したモデル を用い, ヒズミ一時間曲線, ヒズミ速度一時間関係, 加速度一ヒズミ速度等の関係とついて諭じた。ヒズミ一時 間の関係に扔いてはべき乗数 $a=-1$ とすれば第一次クリープ段階が， $a=0$ では第二次定常クリープ段階が, $a \geqq 1$ と扔けば第三次クリープ段階を表わすととが明らかとなった。ヒズミ速度一時間関係からは $a$ を年すれ ば斉藤式中の $\log$ 飞乗ぜられる係数は 1 となること，また加速度一七ズミ速度の関係では $a$ をのとするととね より福圊の提案したヒズミ加速度式のべき乘数は 2 飞等しいととが示された。既往の地すべり, 室内崩買実験等 の資料を今回得られたヒズミ一相対時間関係，ヒズミ速度一相対時間関係湳用するとほほこれらの関係を満足 するとの結論を得た。

表層崩壊発生危険雨量の予測

「地すべり」Vol. 25, No. 1 (通巻第93号) 1988年（昭和63年）6月 駒村富士弥

北海道生田原地すべり地の崩積土とすべり面粘土

「地すべり」Vol. 25, No. 1 (通巻第93号) 1988年（昭和63年）6月 前田 寛之

生田原地すべりは崩積土地すべりである。その地すべりのすべり面は崩積土層中部の連続性のあるレキまじり 粘土層中にある。そのすべり面粘土層は报そらく旧地すべりのすべり面粘土層の一部であると考えられるので, 新地すべりは旧地すべりの下方ブロックが再滑動したものと推定される。その地すべり地の崩積土層の内部構造 と鉱物組合せ, とくにすべり面粘土層の性状は, 新・旧地すべりのすべり面粘土層が招もに泥質岩のスレーキン グや酸性火成岩のいわゆる“まさ”化によって生成されたととを示噯する。

濁沢地すべり地における融雪水・間陌水圧・地下水位・地温の変動特性

「地すべり」Vol. 25, No. 1 (通巻第93号) 1988年（昭和63年）6月

小川 正二, 池田 俊雄, 亀井 健史, 和田 正, 平松 俊英

地すべり地となるける融雪水・間隙水圧・地下水位・地温の变動特性を調べるために現場計測を行った。 その結果, 融雪期の地すべり発生の主要因として膨大な融雪水の地中への浸透が考えられるとと, それによる 間隙水圧上昇時期は地すべりブロック上部と中間部との間でタイムラグがあること，また，気温と地温を計測す るととによって融雪開始時期や融雪水の地中への浸透時期を予測するととが可能となるととが明らかになった。

\section{放山地すべり}

「地すべり」Vol. 25, No. 1 (通巻第93号) 1988年（昭和63年）6月 宮城県砂防課 